\title{
Myelin-Associated Glycoprotein (MAG) in the CNS of Adult Shiverer (Shi/Shi) Mice
}

\author{
H.J. Sheedlo and G.J. Siegel
}

\author{
Department of Neurology, University of Michigan, Ann Arbor, Michigan
}

Brain fractions of adult control $(+/ t)$ and shiverer (Shi/Shi) mice were investigated by sodium dodecyl sulfate-polyacrylamide gel electrophoresis (SDS-PAGE) and immunoblotting. Immunostaining with specific antisera against rat brain myelin-associated glycoprotein (MAG) was detected at about the $96-\mathrm{kD}$ region of gels in electrophoresed samples of the total homogenate, low-speed supernatant fraction, and low- and high-speed sedimentable portions of brain from $+1+$ mice. Reduced immunostaining was observed in the corresponding samples of brain fractions from $\mathrm{Shi} / \mathrm{Shi}$ mice.

The cerebrum, cerebellum, and medulla of $+1+$ and $\mathrm{Shi} / \mathrm{Shi}$ mice were examined immunocytochemically for MAG on paraffin-embedded sections. Periaxonal immunostaining for MAG was observed in all the regions and the highest concentrations were in the corpus callosum, in the central cores of cerebellar folia, and in the medulla. Patterns of distribution were similar in $+1+$ and Shi/ Shi mice, although the density of immunostaining around individual axons and the number of immunostained axons were significantly reduced in Shi/Shi mice. In addition, the three brain regions of Shi/Shi mice exhibited oligodendrocyte-like cells that contained immunostaining for MAG in the cytoplasm and periphery of their perikarya. This type of immunostained cell was not observed in $+1+$ mice.

In this study, immunoblotting with brain fractions and immunocytochemistry revealed strong evidence for reduced concentrations of MAG in the CNS of Shi/ Shi mice compared to control mice. In addition, there is immunocytochemical evidence for abnormal accumulation of MAG in perikarya of oligodendrogliallike cells, suggesting the possibility of a transport block for myelin proteins in the shiverer mutant.

Key words: brain, immunochemistry, immunobiot

\section{INTRODUCTION}

The CNS of shiverer (Shi/Shi) mice is significantly reduced in myelin and in total myelin proteins, of which the major component is myelin basic protein (MBP) [Bird et al, 1978; Mikoshiba et al, 1980; Inoue et al, 1981]. Accordingly, Shi/Shi

Received April 8, 1986; revised July 21, 1986; accepted July 9, 1986.

Address reprint requests to Dr. Harold J. Sheedlo, Department of Neurology, University of Michigan, Neuroscience Laboratory Building, 1103 East Huron, Ann Arbor, MI 48109. 
CNS myelin lacks the major dense line that is formed with MBP [Privat et al, 1979]. The shiverer gene is thought to code for an altered MBP in CNS [Barbarese et al, 1983; Roach et al, 1983].

However, data on other CNS myelin and membrane proteins in Shi/Shi mice are scanty. The myelin enzyme $2^{\prime}, 3^{\prime}$-cyclic nucleotide $3^{\prime}$-phosphodiesterase (CNP) [Mikoshiba et al, 1980], as well as the membrane-bound enzyme $\left(\mathrm{Na}^{+}+\mathrm{K}^{+}\right)$ATPase [Sheedlo et al, 1986] are not reduced in this mutant. It is possible that the defect in MBP synthesis leads to secondary changes in the concentration or distribution of other myelin proteins that are integrated with MBP in myelin development or that the defect in gene expression in oligodendroglia affects many myelin proteins directly. This information may help elucidate normal myelin development.

Myelin-associated glycoprotein, a $100-\mathrm{kD}$ protein, is a minor constituent of the mammalian nervous system. This protein has been localized immunocytochemically to the periaxonal lamellae of myelin sheaths both in the central and peripheral nervous systems [Sternberger et al, 1979; Trapp and Quarles, 1982]. Based on its distribution, it is thought that MAG functions in the interrelationship between the oligodendroglial membrane and the axon [Trapp and Quarles, 1982; Quarles, 1984].

MAG in the brains of myelin-deficient quaking and jimpy mice was reduced by $85 \%$ and $90 \%$, respectively [Frail and Braun, 1985]. Also, Matthieu and co-workers [1974] detected reduced MAG in quaking mouse brain and the major MAG protein exhibited a higher molecular weight than in the control mice. However, the PNS of adult trembler mice, which has a severe myelin deficit, quite surprisingly exhibits a $27 \%$ increase in MAG content [Inuzuka et al, 1985].

With respect to the shiverer mutant, normal MAG synthesis was measured in an in vitro rabbit reticulocyte lysate system using total adult Shi/Shi brain cytoplasmic brain RNA. It was suggested that MAG synthesis in the brains of Shi/Shi mice might be delayed, but that MAG levels would be normal in the adult [Frail and Braun, 1985]. However, there is no information on the concentration or distribution of MAG in the shiverer adult CNS.

The purpose of this study was to determine the cellular distribution of MAG in the CNS of adult myelin-deficient Shi/Shi mice and to determine whether MAG in this mutant is deposited with the same membrane fractions as in those of control mice.

\section{MATERIALS AND METHODS Materials}

Polyacrylamide and polymerizing reagents for electrophoresis and nitrocellulose and the Trans-blot apparatus used in immunoblotting were purchased from Bio-Rad. Diaminobenzidine (DAB), 4-chloro-1-naphthol, SDS, Coomassie blue stain, ATP salts, EDTA, and gel buffer (Trizma, pH 8.8) were obtained from Sigma Chemical Co. Goat anti-rabbit IgG-horseradish peroxidase (HRP) and normal goat serum were purchased from Miles Laboratories. Prestained protein molecular weight standards were obtained from Bethesda Research Lab.

\section{Mice}

Control $(+/+)$ and shiverer (Shi/Shi) male mice at about 60 days of age were used in this study. The breeding stock of shiverer mice (Shi/+) was a kind gift of Dr. T.J. Sprinkle (Augusta, GA). The mice were maintained under NIH guidelines. 


\section{Antigen and Antisera Preparation}

The polyvalent rabbit antiserum raised against rat brain MAG was prepared and characterized as described earlier [Quarles et al, 1981] and was a kind gift of Dr. R. Quarles (Bethesda, MD). The preparation and characterization of $\left(\mathrm{Na}^{+}+\mathrm{K}^{+}\right)$ATPase antigen and antisera have been described elsewhere [Siegel et al, 1984].

\section{Fractionation Procedure}

The brains (cerebrum, cerebellum, and medulla) were excised from $+1+$ and Shi/Shi mice and homogenized in 10 volumes of $0.32 \mathrm{M}$ sucrose, $1 \mathrm{mM}$ EDTA, pH 7.4 (total homogenate), as described previously [Siegel et al, 1984]. After two centrifugation steps the following supernatants and pellets were obtained [Siegel et al, 1984]: P1 (8,500g pellet), S1 $(8,500 \mathrm{~g}$ supernatant), S2 $(30,000 \mathrm{~g}$ supernatant), and $\mathrm{P} 2$ $(30,000 \mathrm{~g}$ pellet $)$. The $30,000 \mathrm{~g}(\mathrm{P} 2)$ pellet was suspended in an incubation mixture $[4$ $\mathrm{mg}$ protein/1 ml, $1 \mathrm{mM}$ EDTA-Tris, $3 \mathrm{mM} \mathrm{Na} 2 \mathrm{ATP}$, and $30 \mathrm{mM}$ imidazole- $\mathrm{HCl}$, $\mathrm{pH} 7.4,0.15 \%(\mathrm{w} / \mathrm{v})$ SDS, $10 \%(\mathrm{w} / \mathrm{w})$ sucrose] as described by Siegel and co-workers [1984]. However, the sucrose gradient was modified as follows (top to bottom): $8 \mathrm{ml}$ $\mathrm{P} 2$ incubation mixture in $10 \%$ sucrose (designated fraction A prior to centrifugation),

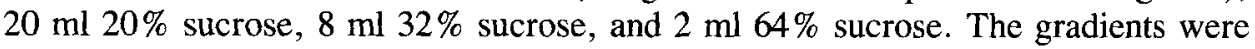
centrifuged in an SW-28 rotor in the Beckman L5-50 at 27,000 rpm $(100,000 \mathrm{~g})$ for 4 hr. The fractions were aspirated from above and designated as follows: B (10\% sucrose), C (10-20\% interface), D (20\% sucrose), E (20-32\% interface), and F (32\% sucrose). The fractions were diluted 10 -fold in water and centrifuged at $39,000 \mathrm{~g}$ (\#19 rotor) overnight, and the final pellets were resuspended in water. The protein content of these fractions was determined by the method of Lowry et al [1951]. Three separate experiments with a total of $19+/+$ and $16 \mathrm{Shi} / \mathrm{Shi}$ mice were used for the preparation of the above fractions.

\section{Electrophoresis and Immunoblot}

Samples of all brain fractions ( $100 \mu \mathrm{g}$ of protein) were added to SDS-gel sample buffer $(2.3 \%$ SDS) and electrophoresed in an SDS-polyacrylamide slab gel $(6 \%$ acrylamide) system as described by Laemmli [1970]. Pairs of companion gels were electrophoresed together, and one gel was stained with Coomassie blue while the second gel was electroblotted to nitrocellulose [Towbin et al, 1979; Siegel et al, 1984]. The nitrocellulose sheets were incubated as follows: blocking solution consisting of $5 \%$ dry milk solids in $10 \mathrm{mM}$ Tris- $\mathrm{HCl}$, pH 7.4, and $0.9 \% \mathrm{NaCl}$ (TBS) [Johnson et al, 1984] for $60 \mathrm{~min}$ at $37^{\circ} \mathrm{C}$; rabbit anti-MAG antiserum $(1: 250)$ for $120 \mathrm{~min}$ at $37^{\circ} \mathrm{C}$; goat anti-rabbit IgG-conjugated-horseradish peroxidase $(1: 2,000)$ for $60 \mathrm{~min}$ at $37^{\circ} \mathrm{C}$, and last, a solution containing $0.05 \%$ diaminobenzidine or $0.05 \%$ 4-chloro1-napthol, $0.03 \%$ hydrogen peroxide $\left(\mathrm{H}_{2} \mathrm{O}_{2}\right), 1 \%$ acetone, and TBS for $5 \mathrm{~min}$. The antisera were diluted with $10 \%$ normal goat serum, $5 \%$ dry milk solids in TBS. The nitrocellulose sheets were rinsed for $30 \mathrm{~min}$ with TBS after each incubation with the primary and secondary antisera.

In one experiment, duplicate tracks containing $100 \mu \mathrm{g}$ of fraction $\mathrm{D}$ and $\mathrm{P} 1$ pellet of $+1+$ mice were electrophoresed on a single slab and electroblotted to nitrocellulose as described above. The tracks were bisected and incubated with $\left(\mathrm{Na}^{+}+\mathrm{K}^{+}\right)$-ATPase $(1: 200)$ or MAG $(1: 250)$ antisera to localize their respective positions on immunoblots. 


\section{Immunocytochemistry}

Six each of $+1+$ and Shi/Shi mice were perfused with $4 \%$ paraformaldehyde in $0.1 \mathrm{M}$ sodium phosphate, $\mathrm{pH} 7.4$. The brain regions (cerebrum, cerebellum, and medulla) were sectioned sagitally (1-2 mm thick), fixed for an additional $4 \mathrm{hr}$ at room temperature, and embedded in paraffin.

Paraffin sections $(5 \mu \mathrm{m})$ were mounted on gelatin-coated slides, incubated, and immunostained with anti-MAG as described for other antisera [Siegel et al, 1984; Sheedlo et al, 1986]. Primary and secondary (anti-rabbit-conjugated HRP) antibodies were diluted $1: 250$, and rabbit preimmune serum was diluted $1: 200$ in $1 \%$ goat serum in $0.1 \mathrm{M}$ phosphate-buffered saline (PBS), $\mathrm{pH}$ 7.4. MAG immunostaining was visualized by treating the sections with $0.025 \%$ diaminobenzidine, $0.01 \% \mathrm{H}_{2} \mathrm{O}_{2}$ in

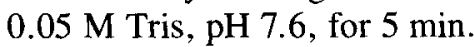

\section{RESULTS}

\section{Electrophoresis and Immunoblot}

As shown by SDS-PAGE and immunoblotting, the total brain homogenates from $+1+$ and Shi/Shi mice exhibited a MAG-like immunoreactive band of $\mathrm{Mr}$ about 96,000 (Fig. 1A, lanes 2,3). Further, immunoblotting of purified MAG (a gift of Dr. R. Quarles) in our 6\% gel system showed a MAG-immunostained band in the $96-\mathrm{kD}$ region, as determined by the Rf value (not shown). All brain samples in both $+1+$ and Shi/Shi mice, except the S2 fractions (lanes 6 and 7), showed immunostaining for MAG; however, the immunostaining in Shi/Shi brain samples was reduced, indicating a reduction in MAG content. The $\mathrm{P} 1$ and $\mathrm{P} 2$ pellets of $+1+$ mice brain exhibited the most intense staining for MAG, whereas reduced staining was detected in the corresponding pellets of Shi/Shi mice brain (Fig. 1A, lanes 8-11). All brain fractions from $+1+$ and Shi/Shi mice showed identical Coomassie blue stain patterns in the $96-\mathrm{kD}$ region of the gels in which MAG immunostain was found (Fig. 1B). The amount of MAG in these samples is too small to be obvious by protein stain alone. MAG immunostaining in the sucrose gradient fractions was faint in the $10 \%$ sucrose fraction (B) and at the 10-20\% sucrose interface (C), but amounted to only a trace or was not detectable in $20 \%$ and higher sucrose fractions from $+1+$ mice or in any of the sucrose fractions from Shiverer mice (not shown).

$\left(\mathrm{Na}^{+}+\mathrm{K}^{+}\right)$-ATPase in fraction $\mathrm{D}$ and $\mathrm{P} 1$ pellet was shown by immunoblotting to migrate to about the $110-\mathrm{kD}$ region in the $6 \%$ acrylamide gel system (Fig. 2A, lanes 2a,3b). However, MAG immunostaining in the two samples was observed at the $96-\mathrm{kD}$ region (Fig. 2A, lanes $2 \mathrm{~b}, 3 \mathrm{a}$ ).

The Coomassie blue-stained gel reveals a band in fraction $D$, which contains high $\left(\mathrm{Na}^{+}+\mathrm{K}^{+}\right)$-ATPase, and the P1 pellet above the $94.7-\mathrm{kD}$ standard (Fig. 2B, lanes 2,3). This band corresponds to the $\left(\mathrm{Na}^{+}+\mathrm{K}^{+}\right)$-ATPase immunostained band in respective samples in the immunoblot (Fig. 2A, lanes $2 \mathrm{a}, 3 \mathrm{~b}$ ).

As a technical note, the immunoblots stained for MAG, especially the DABtreated blot, revealed a doublet that may result from the dense accumulation of the comigrating protein to about the $110-\mathrm{kD}$ region (Fig. 1A). It is possible that the comigrating protein is $\left(\mathrm{Na}^{+}+\mathrm{K}^{+}\right)$-ATPase, as immunoblots of mouse brain fractions immunostained with $\left(\mathrm{Na}^{+}+\mathrm{K}^{+}\right)$-ATPase antisera reveal a band in the $110-\mathrm{kD}$ region (Fig. 2A, lane 3b). 


\section{Immunocytochemistry}

In the central cores of the cerebellar folia, the number of nerve fibers that exhibited immunostaining for MAG in the periaxonal region were significantly reduced in Shi/Shi mice (Fig. 3B) compared to that in control mice (Fig. 3A). Cells having the morphology of oligodendrocytes were immunostained for MAG at the periphery and within the cytoplasm of the cell body in the cerebellar central cores of Shi/Shi mice (Fig. 3C). Similar cells could not be found in sections from $+1+$ mice.

There was a significantly greater number of nerve fibers exhibiting periaxonal staining for MAG in the corpus callosum of $+/+$ mice (Fig. 4A) than in the corpus callosum of Shi/Shi mice (Fig. 4B). MAG-immunostained nerve fibers were visible extending into the cerebral cortex (cc) of $+/+$ mice (Fig. $4 C$ ) but not into that of Shi/Shi mice (Fig. 4D). Oligodendrocyte-like cells in the corpus callosum of Shi/Shi mice, but not $+1+$ mice, were immunostained for MAG at the periphery of the cell body and within the cytoplasm (Fig. 4D).

Immunostaining for MAG in the medulla was distributed along nerve fibers (periaxonal) in $+1+$ (Fig. 5A) and Shi/Shi mice (Fig. 5B), although the number of stained fibers and the density of staining were significantly reduced in medulla of Shi/ Shi mice compared to that in control mice (compare Figs. 5A,5B). As in the corpus callosum and cerebellar central cores, oligodendrocyte-like cells in the medulla also were immunostained for MAG at the periphery and within the cytoplasm of their perikarya (Fig. 5C). Similarly stained cells could not be found in sections from $+1+$ medulla.

\section{DISCUSSION}

The immunocytochemical and immunoblotting results in this study show a large reduction in CNS MAG in adult Shi/Shi mice. The periaxonal distribution of MAG immunostaining along nerve fibers in both $+/+$ and Shi/Shi mice appears similar to that shown by Sternberger and co-workers [1979] and by Trapp and Quarles [1984] in rat and mice.

In a radioimmunoassay study, whole-brain homogenates of 4- to 6-week-old Shi/Shi mice exhibited a $57 \%$ reduction in MAG content compared to that of control mice (Quarles and Knobler, personal communication). The immunocytochemical and immunoblot results in our study are consistent with this radioimmunoassay study.

The novel finding of MAG-like immunostaining in the oligodendrocyte-like cells in cerebellum, cerebrum, and medulla from Shi/Shi mice and not from $+1+$ mice is of interest. This observation may indicate that MAG is synthesized at normal or near normal levels and that it accumulates in the cytoplasm in Shi/Shi mice because it is not transported to the cell processes for integration into myelin. The block may be at the level of myelin assembly or, proximally, in transport. MAG in Shi/Shi mice seems to be associated with the same membrane fragments as $+1+$ mice, as shown by the similar distribution in various sedimentable brain fractions (Fig. 1A). The potential for synthesis of MAG appears to be preserved in the Shiverer mutant, a finding that is consistent with the in vitro data of Frail and Braun [1985].

MAG-immunostained satellite oligodendrocytes and their processes were also detected in the spinal cord of a 90-day-old Shiverer mouse, although this experiment was not complete with controls [Sternberger, 1984]. 

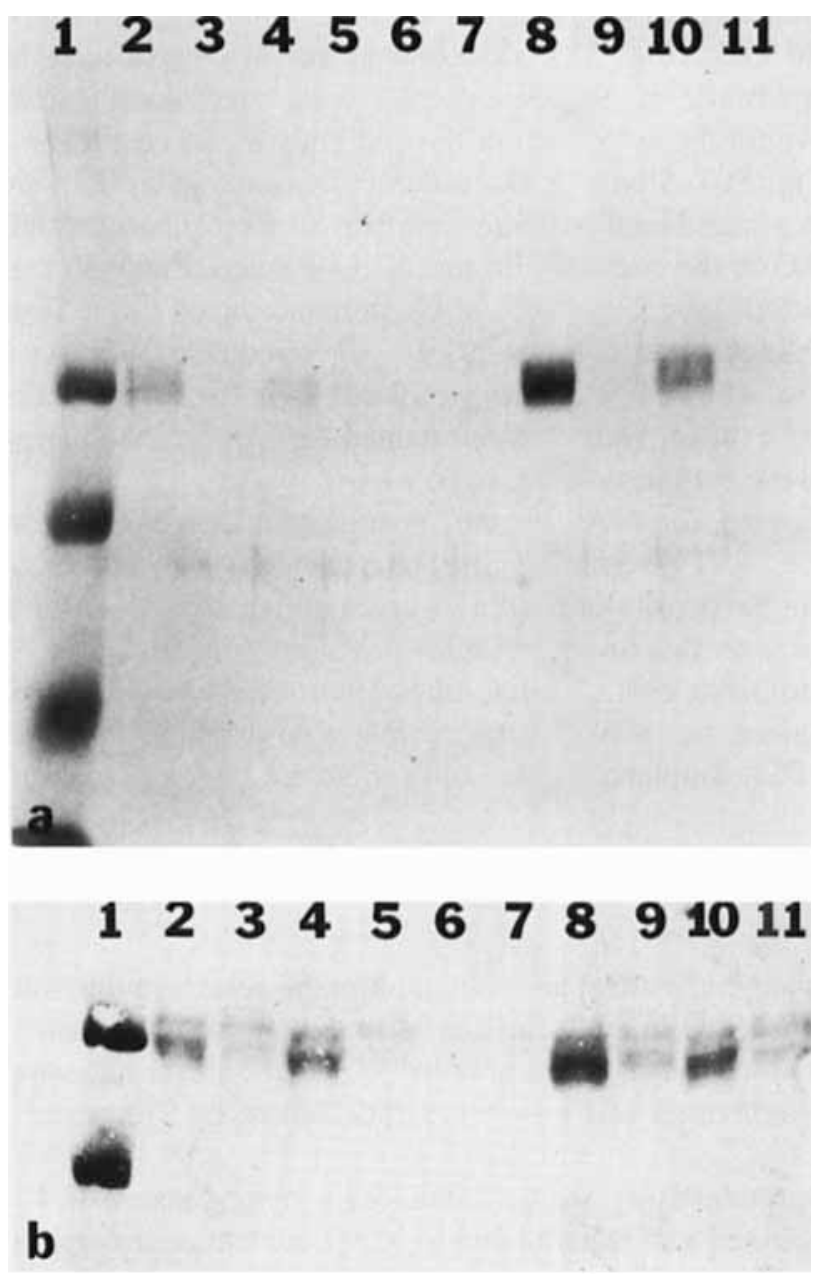

Fig. 1. A. Immunoblot characterization of MAG in brain fractions of $+/+$ and Shi/Shi mice. Samples containing $100 \mu \mathrm{g}$ protein of each brain fraction were electrophoresed in a $6 \%$ acrylamide gel system, and the gel was electroblotted to a nitrocellulose sheet. The sheets were incubated first with MAG antiserum (1:250) and then with goat anti-rabbit IgG-HRP $(1: 2,000)$ as described in Methods. a, b. Immunoblots treated with 4-chloro-1-naphthol and DAB as a substrate, respectively. Lane 1: Prestained protein standards (top to bottom): myosin (200 kD), phosphorylase $\mathbf{B}(94.7 \mathrm{kD})$, bovine serum albumin $(67 \mathrm{kD})$, and ovalbumin $(43 \mathrm{kD})$; lane $2:+/+$ total homogenate $(\mathrm{TH})$; lane $3:$ Shi/Shi TH; lane $4:+1$ + low-speed (8,500 g) supernatant (S1); lane 5: Shi/Shi S1; lane 6: +/+ high-speed (30,000 g) supernatant (S2); Iane 7: Shi/Shi S2; lane 8: $+/+$ low-speed $(8,500$ g) pellet (P1); lane 9: Shi/Shi P1; lane 10: $+1+$ high-speed pellet (P2); lane 11: Shi/Shi P2. MAG immunostaining was observed in all brain fractions of $+i+$ and Shi/Shi mice, except the $S 2$ fraction, at about the $96-\mathrm{kD}$ region of the immunoblot. Reduced staining was apparent in each of the brain fractions of Shi/Shi compared to the corresponding fractions from $+1+$ mice. Staining at the level of $65 \mathrm{kD}$ was an inconsistent artifact related to gel contaminants. B. Coomassie blue-stained gel showing brain fractions of $+/+$ and Shi/Shi mice corresponding to the immunoblot in $\mathrm{A}$. The gel was electrophoresed together with that in $\mathrm{A}$; the lanes are as indicated in A. No difference in stained protein bands in the region of MAG immunostaining $(96 \mathrm{kD})$ was detected between corresponding fractions of $+/+$ and Shi/Shi mice. 


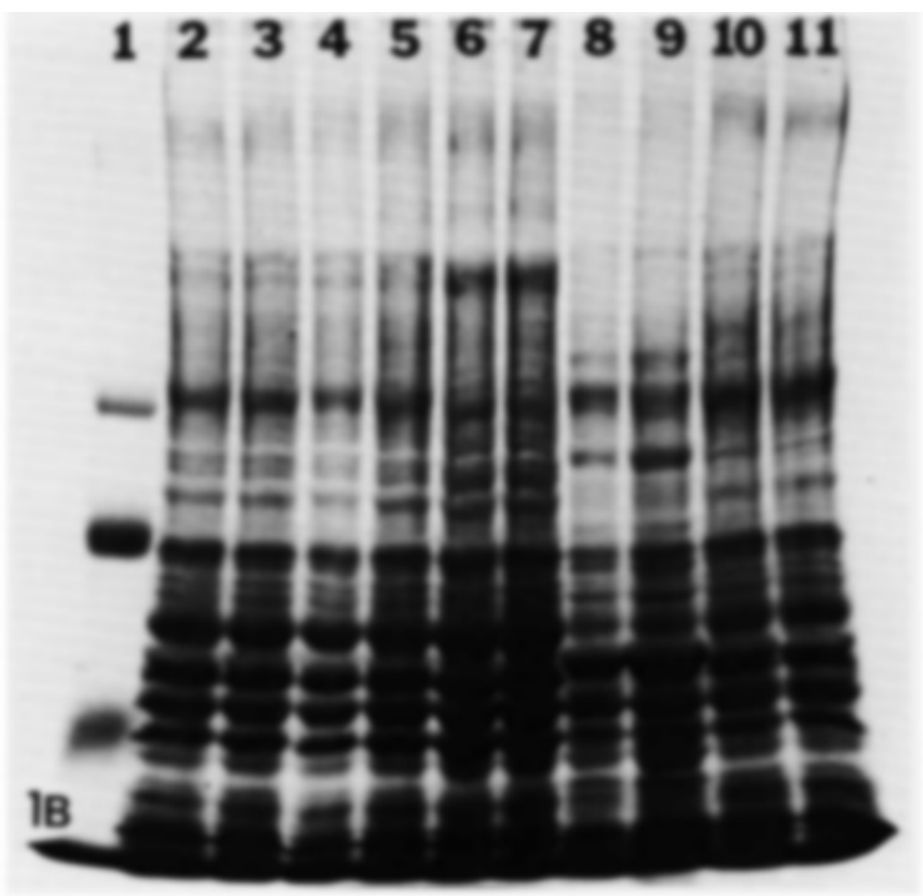

Fine IB.
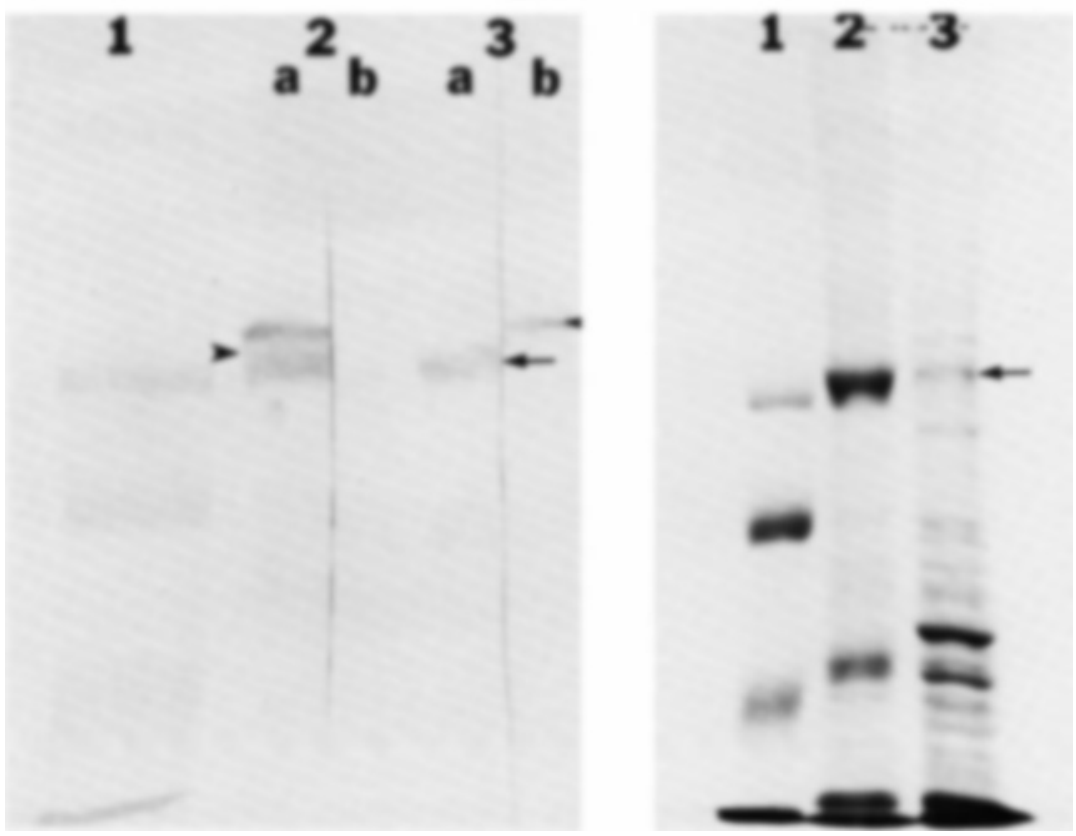

Fig. 2. A. Separation of $\left(\mathrm{Na}^{+}+\mathrm{K}^{+}\right)$-ATPase and MAG by SDS-PAGE. Electrophoresis and immunoblotting were performed as described in Methods. Each sample consisted of $100 \mu \mathrm{g}$ protein. Lane 1: prestained protein standards as in Figure $1 \mathrm{~A}$; lane $2 \mathrm{a}$ : $\left(\mathrm{Na}^{+}+\mathrm{K}^{+}\right)$-ATPase immunostaining in $+1+$ fraction D; lane 2b: MAG immunostaining in $+1+$ fraction D; lane 3a: MAG immunostaining in $+1+$ $\mathrm{P} 1$ pellet; lane $3 \mathrm{~b}$ : $\left(\mathrm{Na}^{+}+\mathrm{K}^{+}\right)$-ATPase immunostaining in $+1+\mathrm{P} 1$ pellet. The immunoblot showed immunostaining for $\left(\mathrm{Na}^{+}+\mathrm{K}^{+}\right.$)-ATPase (arrowheads) at about the $110-\mathrm{kD}$ region and MAG (arrow) at about the $96-\mathrm{kD}$ region in both fraction $\mathrm{D}$ and $\mathrm{P} 1$ pellet. $\mathrm{B}$. Coomassie blue-stained gel of $+/+$ brain fractions corresponding to the immunoblot in A. Samples consisted of $100 \mu \mathrm{g}$ protein. Lane 1: prestained protein standards; lane $2:+/+$ brain fraction $\mathrm{D}$; lane $3:+/+$ brain $\mathrm{P} 1$ pellet. $\left(\mathrm{Na}^{+}+\mathrm{K}^{+}\right)$-ATPase is clearly stained above the $94.7 \mathrm{kD}$ (phosphorylase $\mathrm{B}$ ) protein standard in the $+/+$ fraction $\mathrm{D}$, whereas a less broad corresponding band was detected in the $+l+$ P1 pellet (arrow). 

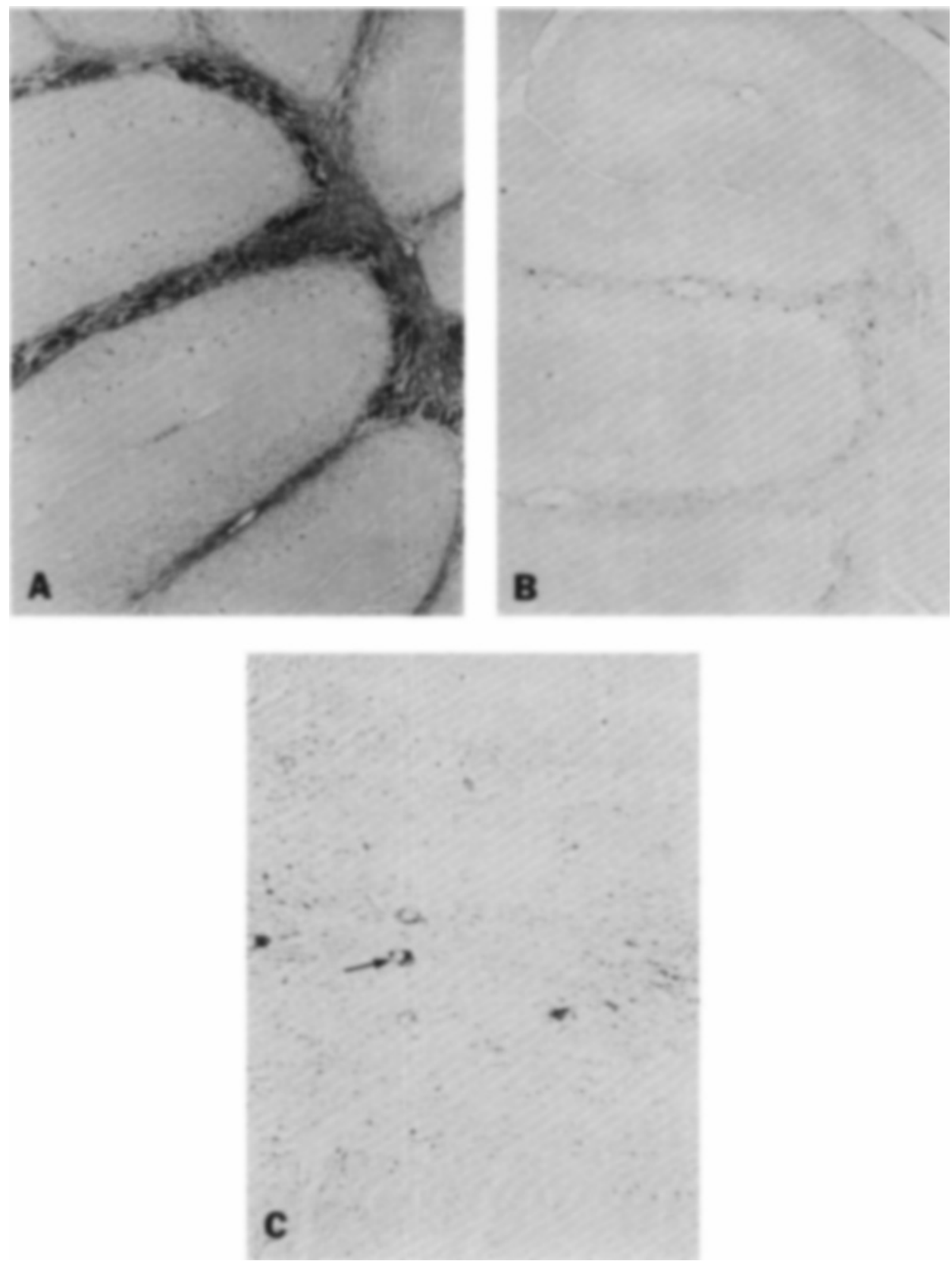

Fig. 3. Immunocytochemical localization of MAG in the cerebellum of $+1+$ and Shi/Shi mice. A. $+/+$ cerebellum; B. Shi/Shi cerebellum. MAG immunostain was detected in the periaxonal region of nerve fibers in the cerebellar central cores of both $+1+$ and Shi/Shi mice, although fewer MAG-stained fibers were apparent in the cerebellum of Shi/Shi mice than in $+1+$ mice. C. Shi/Shi cerebellum. Cells, morphologically resembling oligodendrocytes, were immunostained for MAG at the periphery and within the cytoplasm of the perikarya (arrow). D. $+1+$ cerebellum, preimmune serum. E. Shi/Shi cerebellum, preimmune serum. Substituting rabbit preimmune serum for MAG antisera resulted in no detectable reaction product in the cerebellum of either $+/+$ or Shi/Shi mice. Original magnification: $A, B, D, E$ : $50 \times ; \mathrm{C}: 240 \times$. 


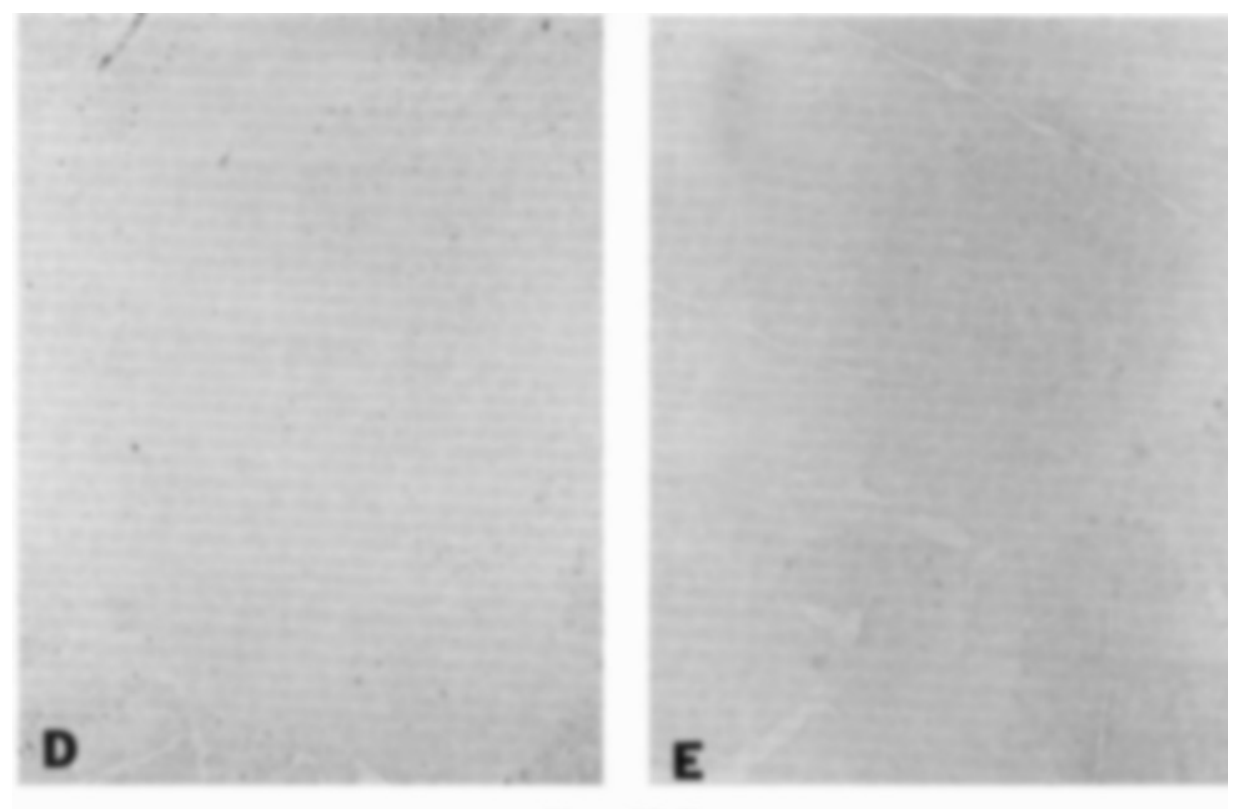

Fine 30,E.
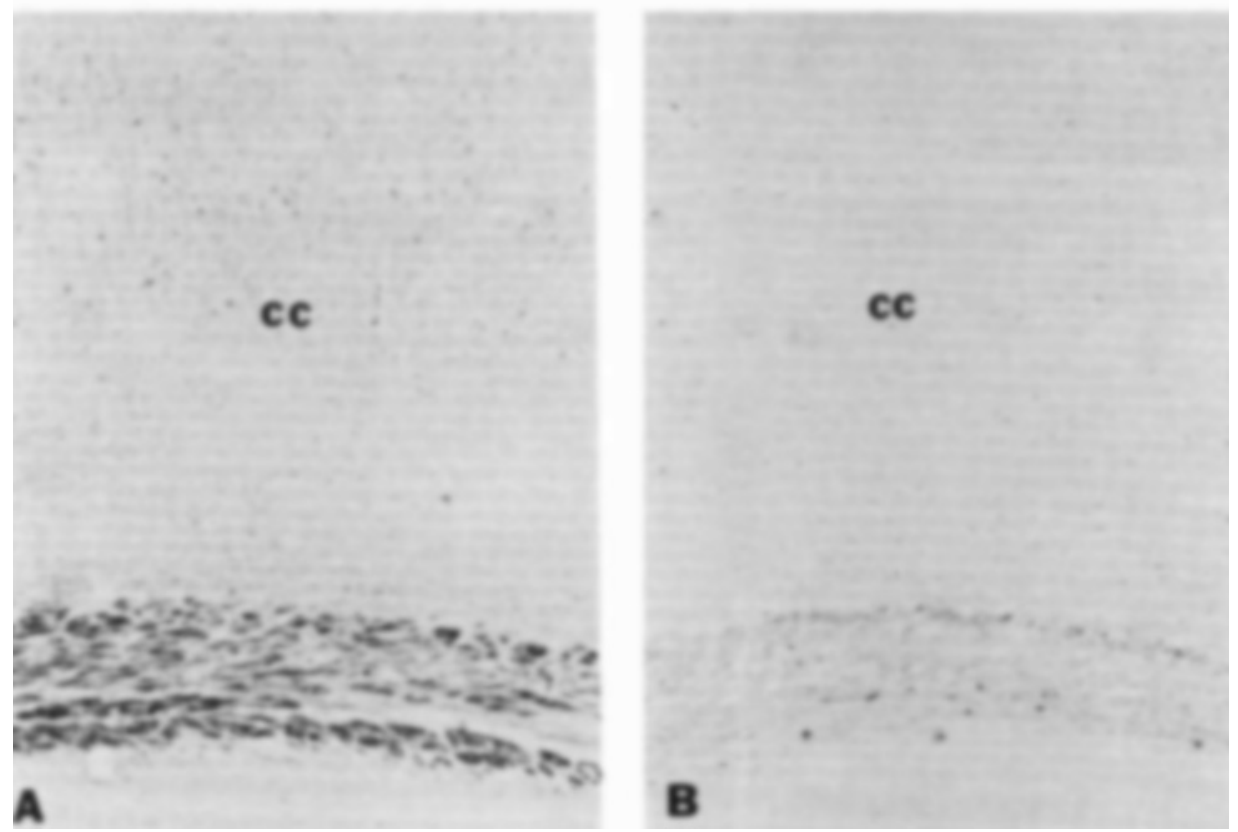

Fig. 4. Immunocytochemical localization of MAG in the cerebrum of $+/+$ and Shi/Shi mice. A. $+/+$ cerebrum. B. Shi/Shi cerebrum. Periaxonal MAG-immunostained nerve fibers are especially apparent in the corpus callosum (cc) of $+/+$ mice, with fewer stained fibers in the identical region of Shi/Shi mice. C. $+1+$ cerebrum. D. Shi/Shi cerebrum. MAG-stained fibers are evident passing from the corpus callosum into the cerebral cortex of $+1+$ but not into cortex of Shi/Shi mice. Additionally, the periphery and cytoplasm of oligodendrocyte-like cells (arrow) were immunostained for MAG in the corpus callosum of Shi/Shi mice (D). E. $+1+$ cerebrum, preimmune serum. F. Shi/Shi cerebrum, preimmune serum. Incubation of cerebral sections with preimmune instead of immune serum resulted in no detectable immunoreactive product for MAG. Original magnification: A,B: $100 \times ; \mathrm{C}, \mathrm{D}: 240 \times ; \mathrm{E}, \mathrm{F}$ : $60 \times$. 

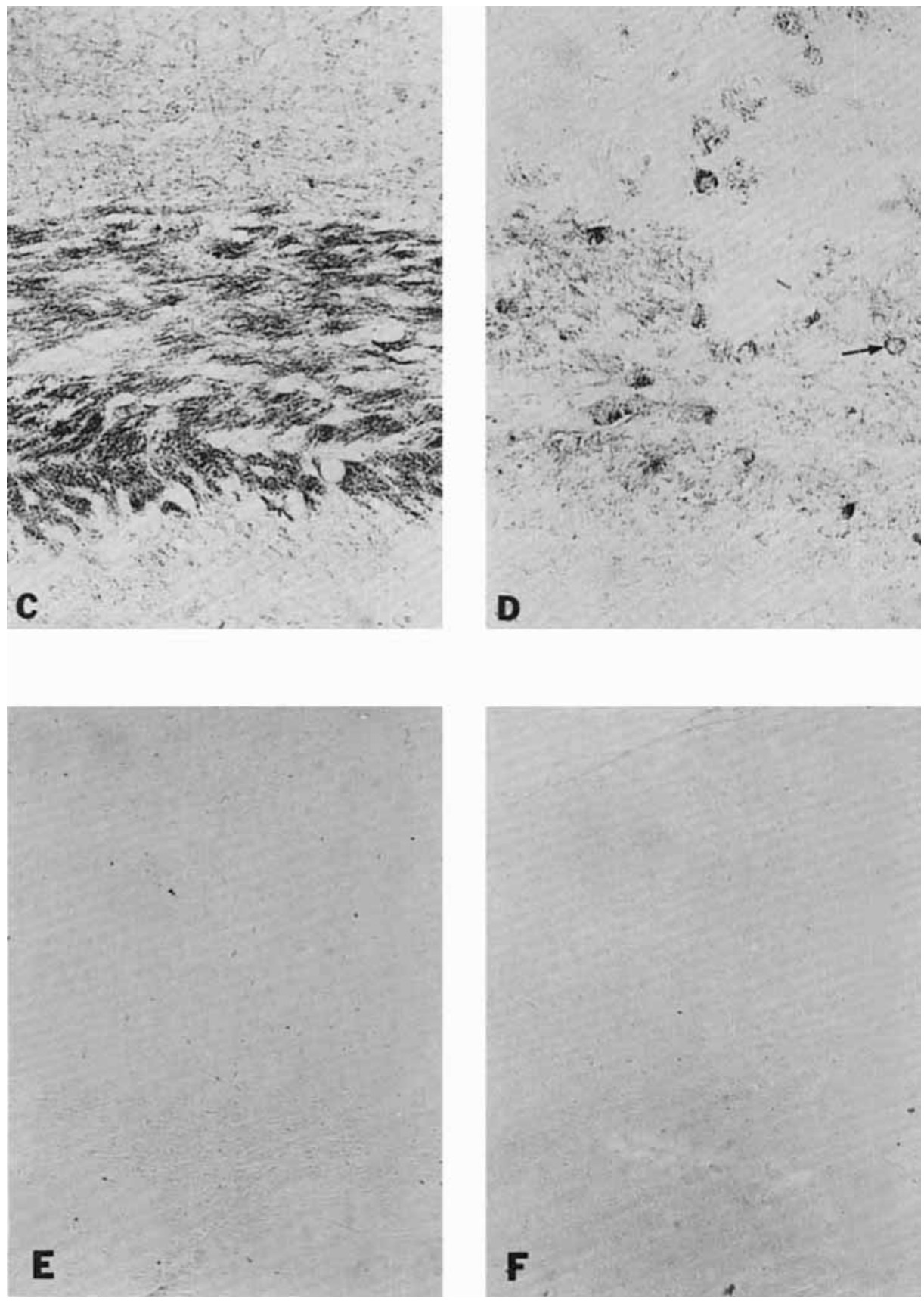

Figure 4C-F 

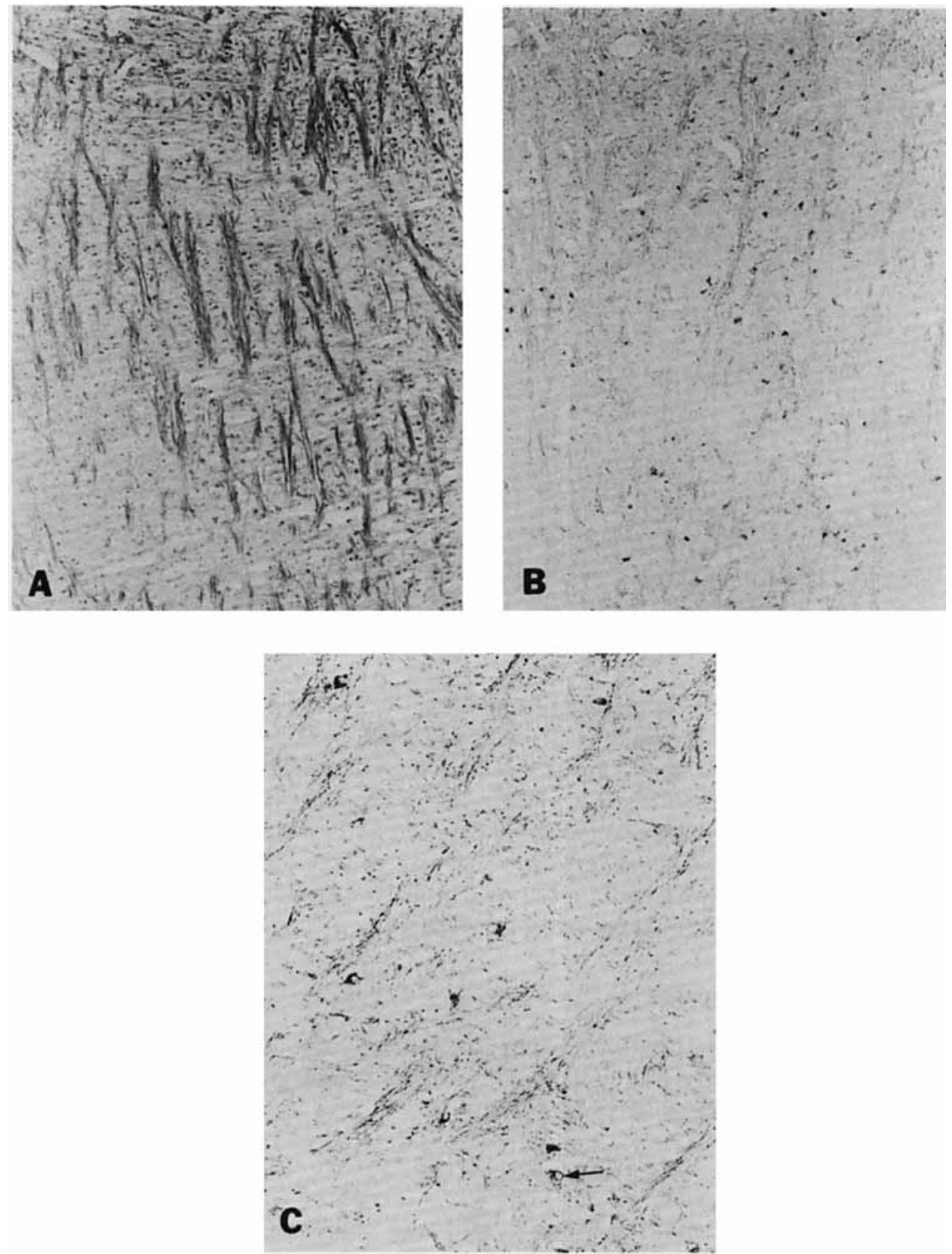

Fig. 5. Immunocytochemical localization of MAG in the medulla of $+1+$ and Shi/Shi mice. A. $+1+$ medulla. B. Shi/Shi medulla. The medulla of Shi/Shi mice showed fewer MAG-immunostained fibers (periaxonal) than did the same region of $+/+$ mice. C. Shi/Shi medulla. In the medulla of Shi/Shi mice, cells that resemble oligodendrocytes (arrow) were stained for MAG at the periphery and within the cytoplasm of their perikarya. D. $+/+$ medulla, preimmune serum. E. Shi/Shi medulla, preimmune serum. Incubation of medulla sections with preimmune instead of immune serum resulted in no detectable immunoreactive product for MAG. Original magnification: A,B: $80 \times$; C: $240 \times ;$ D,E: $80 \times$. 

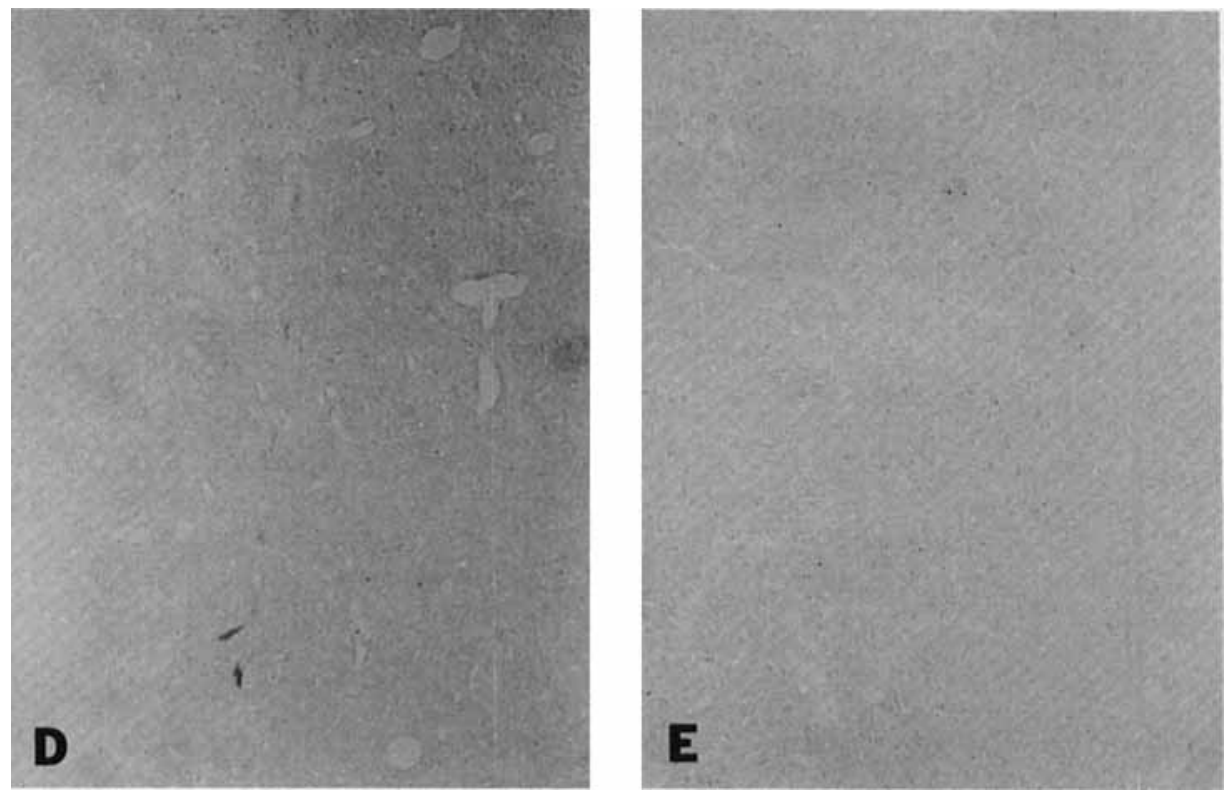

Figure 5D,E

In conclusion, the amounts of at least two membrane enzymes in the CNS of Shi/Shi mice, CNP [Mikoshiba et al, 1980] and $\left(\mathrm{Na}^{+}+\mathrm{K}^{+}\right)$-ATPase [Sheedlo et al, 1986], are not affected by the shiverer gene or by reduced CNS myelin, whereas the myelin proteins MAG (this study), MBP, and proteolipid protein [Mikoshiba et al, 1980] are significantly reduced in myelin-deficient Shi/Shi mice. Additionally, MAG appears to accumulate in oligodendrocyte-like cells in the CNS of the shiverer mutant, suggesting a block in transport of proteins destined for myelin assembly. The mechanism for such transport requires further elucidation.

\section{ACKNOWLEDGMENTS}

Thanks are extended to Timothy J. Desmond for technical assistance and Marjorie Mills for secretarial support. This study was supported by National Institute of Health grants NS 15935 and NS 07222.

\section{REFERENCES}

Barbarese E, Neilson ML, Carson JH (1983): The effect of the shiverer mutation on myelin basic protein expression on homozygous and heterozygous mouse brain. J Neurochem 40:1680-1686.

Bird TD, Farrell DF, Sumi SM (1978): Brain lipid composition of the shiverer mouse (genetic defect in myelin development). J Neurochem 31:387-391.

Frail DE, Braun PE (1985): Abnormal expression of the myelin-associated glycoprotein in the central nervous system of dysmyelinating mutant mice. $J$ Neurochem 45:1071-1075.

Inoue Y, Nakamura R, Mikoshiba K, Tsukada Y (1981): Fine structure of the central myelin sheath in the myelin deficient mutant shiverer mouse, with special reference to the pattern of myelin formation by oligodendroglia. Brain Res 219:85-94.

Inuzuka T, Quarles RH, Heath J, Trapp BD (1985): Myelin-associated glycoprotein and other proteins in Trembler mice. J Neurochem 44:793-797. 
Johnson DA, Gautsch JW, Sportsman JR, Elder JH (1984): Improved technique utilizing nonfat dry milk for analysis of proteins and nucleic acids transferred to nitrocellulose. Gene Anal Tech 1:3-8.

Laemmli UK (1970): Cleavage of structural proteins during the assembly of the head of bacteriphage T4. Nature 227:680-685.

Lowry OH, Rosebrough NH, Farr AC, Randall RJ (1951): Protein measurements with the Folin phenol reagent. J Biol Chem 193:265-275.

Matthieu J-M, Brady RO, Quarles RH (1974): Anomalies of myelin-associated glycoproteins in 'Quaking' mice. J Neurochem 22:291-296.

Mikoshiba K, Aoki E, Tsukada Y (1980): 2'3'-Cyclic nucleotide $3^{\prime}$-phosphohydrolase activity in the central nervous system of a myelin deficient mutant (shiverer). Brain Res 192:195-204.

Privat A, Jacque C, Bourre JM, Dupouey P, Baumann N (1979): Absence of the major dense line in myelin of the mutant mouse 'Shiverer.' Neurosci Lett 12:107-112.

Quarles RH (1984): Myelin-associated glycoprotein in development and disease. Dev Neurosci 6:285303.

Quarles RH, Johnson D, Brady RO, Sternberger NH (1981): Preparation and characterization of antisera to the myelin-associated glycoprotein. Neurochem Res 6:1115-1127.

Roach A, Boylan K, Horvath S, Prusiner SB, Hood LE (1983): Characterization of clones cDNA representing rat myelin basic protein: Absence of expression in brain of Shiverer mutant mice. Cell 34:799-806.

Sheedlo HJ, Desmond TJ, Siegel GJ (1986): $\left(\mathrm{Na}^{+}+\mathrm{K}^{+}\right)$-ATPase and MAG localization in the CNS and PNS of Shiverer mice. Trans Am Soc Neurochem 17:278.

Siegel GJ, Holm C, Schreiber JH, Desmond T, Ernst SA (1984): Purification of mouse brain $\left(\mathrm{Na}^{+}+\mathrm{K}^{+}\right)$-ATPase catalytic unit, characterization of antiserum, and immunocytochemical localization in cerebellum, choroid plexus, and kidney. J Histochem Cytochem 32:1309-1318.

Sternberger NH (1984): Patterns of oligodendrocyte function seen by immunocytochemistry. Norton WT (ed): "Oligodendroglia." New York: Plenum, pp 125-173.

Sternberger NH, Quarles RH, Itoyama Y, Webster H deF (1979): Myelin-associated glycoprotein demonstrated immunocytochemically in myelin and myelin-forming cells of developing rat. Proc Natl Acad Sci USA 76:1510-1514

Towbin H, Staehelin T, Gordon J (1979): Electrophoretic transfer of proteins from polyacrylamide gels to nitrocellulose sheets: Procedure and some applications. Proc Natl Acad Sci USA 76:43504354.

Trapp BD, Quarles RH (1982): Presence of the myelin-associated glycoprotein correlates with alteration in the periodicity of peripheral myelin. J Cell Biol 92:877-882.

Trapp BD, Quarles RH (1984): Immunocytochemical localization of the myelin-associated glycoprotein Fact or artifact? J Neuroimmunol 6:231-249. 